\title{
Microbiological Quality of Attiéké (Steamed Cassava Semolina) Sold in Côte d'Ivoire
}

\author{
KPATA-KONAN Nazo Edith (Corresponding Author) \\ UFR Agroforesterie, University Jean Lorougnon Guédé, \\ BP 150 Daloa, Côte d'Ivoire
}

Tel: 225-0563-4582 E-mail : kpataedith@gmail.com

YAO N'Zué Benjamin

UFR Agroforesterie, University Jean Lorougnon Guédé, BP 150 Daloa, Côte d'Ivoire

Tel: 225-0563-4582_E-mail : nzuebenjamin@yahoo.fr

\section{COULIBALY Kalpy Julien}

Département Environnement - Santé,

Institut Pasteur de Côte d'Ivoire, Abidjan, Côte d'Ivoire

Tel: 225-2244-1172_E-mail :jc_kalpy@yahoo.fr

KONATÉ Ibrahim

UFR Agroforesterie, University Jean Lorougnon Guédé, BP 150 Daloa, Côte d'Ivoire

Tel: 225-0563-4582_E-mail : konatibrahim@yahoo.fr

Received: June 13, 2020

Doi: 10.5296/jab.v8i2.17169
Accepted: July 22, 2020

Published: July 24, 2020

URL: https://doi.org/10.5296/jab.v8i2.17169 


\section{Abstract}

This article looked at the quantity and storage time of attiéké produced and sold in the town of Daloa. It also examines the microbiological characteristics of attiéké-femme and attiéké-garba from this locality during storage. The study was carried out on the one hand through a field survey carried out on the producers and sellers. On the other hand, a sample was taken from 10 sellers of attiéké-garba and 10 sellers of attiéké-woman. The study found that the women producers sell $87 \%$ of their production in the city of Daloa and export $13 \%$. In addition, attiéké can be kept for 2 days at the producers and beyond 2 days at the sellers before their stock runs out. Therefore, a weekly production of more than $200 \mathrm{~kg}$ for the majority of the producers is observed. Microbiological analyses showed high levels of germs (MAG: $6.106 \mathrm{CFU} / \mathrm{g}$; Yeasts and moulds: 2.7.106 CFU/g) for attiéké-women and $(2.106$ $\mathrm{CFU} / \mathrm{g}$ of GAM and 1.6.103 CFU/g of Yeasts and moulds) for attiéké-garba. Total coliforms and faecal coliforms were only found in attiéké-women. No salmonella was observed. In view of the results, it should be noted that female attiéké is the most contaminated type of attiéké.

Keywords: Attiéké (steamed cassava semolina), Cassava, Microbiological quality, Côte d'Ivoire

\section{Introduction}

In Côte d'Ivoire, attiéké (steamed cassava semolina) is the main food use of cassava tuberous roots (Kakou, 2000). Originally from the south (Djè et al., 2008), this dish is now produced and consumed throughout Côte d'Ivoire and by all socio-economic strata. According to Djéni et al (2008), Attiéké's consumption is estimated at more than 450,000 tons per year. Nowadays, it has found its way beyond the borders of Côte d'Ivoire, becoming one of the best-known foods across francophone Africa, Europe, North America, and Asia through the black African diaspora (Djéni et al., 2011). This food can be consumed in different ways. These include Attiéké with smoked fish (APF), attiéké associeted to sauce or soup, attiéké with braised chicken, attiéké with fried tuna fish commonly call garba.

Very popular in Côte d'Ivoire where it has become a national dish, attiéké owes its strong propensity in the fact that it constitutes a fast and cheap food (Assanvo et al., 2006).

It accounts for about $5 \%$ of food expenditure and $20.5 \%$ of calories in the food ration of many Ivorian populations (Krabi et al., 2015). The distribution of attiéké ready to be marketed is mainly carried out by portage, cart and van, because despite the dynamism of the actors in the attiéké sector, transport conditions remain almost traditional.

However, contamination with microorganisms such as yeasts and moulds, mesophilic aerobic germs, total coliforms, and salmonella genus can be observed.

Therefore, some of them, producers of secondary metabolites like toxins, representing a real danger for the consumer (Kouadio, 2012; Yéboué et al., 2017). Indeed, the most frequent contaminants are observed during the manufacture of attiéké taking place under precarious hygienic conditions (Coulin et al., 2006) and during its storage in unsanitary sales outlets. In 
addition, the level of individual ownership of the sellers is worrying.

Several works on attiéké have been carried out, in particular on the cassava ferment for the production of attiéké (Assanvo et al., 2002), its cold conservation (Sahore \& Nemlin, 2010), the composition of dehydrated attiéké (Yao et al., 2006), the nutritional and organoleptic qualities of attiéké ( Dédédji et al., 2008). Few studies focused microbiological aspect related to the storage of attiéké in the places of production and sale have been done.

The present work aims to draw the attention of the Ivorian population, in particular that of the town of Daloa, to the microbiological quality of attiéké stored in the points of sale, suitable for consumption.

\section{Materials and Methods}

\subsection{Biological Material and Survey}

The biological material used in this work is cassava (Manihot esculenta) of the Yace variety, grown in Haut- Sassandra region (Central west of Côte d'Ivoire). The processing of cassava yields several dishes, including the steamed cassava semolina "attiéké" (Figure 1) which is the subject of our study.

A survey took place in order to have information about quantity of attiéké produced and its storage or conservation time. Sixty-eight (68) women producers and 20 sellers of attiéké (10 attiéké-garba sellers and 10 attiéké-women sellers) were questioned.

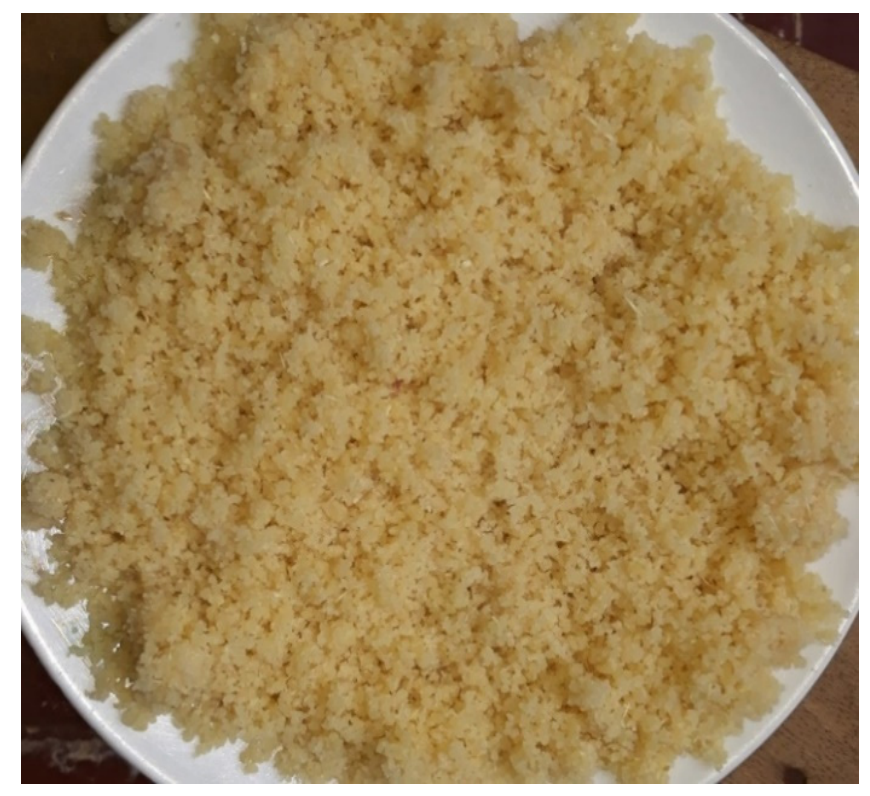

Figure 1. Photograph of attiéké (steamed cassava semolina)

\subsection{Sampling Methods}


Microbial flora associated with attieké was determined on two types of samples in order to determine the microbiological quality of the products consumed according their storage time. The samples were taken from vendors (10 attiéké-garba vendors and 10 attiéké-women vendors) taken randomly in 10 districts of the city of Daloa, namely a sample by vendor. These were the Tazibouo, Evêché, Lobia, Soleil, Kennedy, Huberson Commerce, Garage and Orly neighbourhoods. These selected districts among many others are spread throughout Daloa's city. They are located in the four corners of the city which will make it possible to obtain representative data of the said city

For each seller, an aliquot is taken from all the baskets to give a total of 20 samples. They were then packed in polyethylene bags, placed in a cooler and transported under aseptic conditions to the laboratory for bacteriological analysis.

In general, attiéké-garba is sold by men and is composed of attiéké and tuna fish, while Attiéké said attiéké-woman is sold by women and is a mixture of attiéké and horse "mackerel" fish.

\subsection{Microbiological Analyses}

The microbiological analyses carried out focused on the enumeration and identification of bacteria commonly sought to determine the microbiological quality of a food.

The search and enumeration of mesophilic aerobic germs were carried out according to NF V 08-051. Those of total coliforms or coliforms at $37{ }^{\circ} \mathrm{C}$ and Yeasts and moulds were done respectively according to NF V 08-050 and the ISO 21527-1:2008 standard.

Pathogen's agents analysis was based on the presence of salmonella. This research was carried out according to the method described in the ISO 6579:2002 standard.

\section{Results and Discussion}

\subsection{Results}

\subsubsection{Production of Attiéké}

In Daloa's city, 200 to $300 \mathrm{~kg}$ of attiéké were produce per week by $74 \%$ of producers when $15 \%$ produce 300 to $450 \mathrm{~kg}$ and 11\% supply more than $450 \mathrm{~kg}$ (Figure 2a). 100\% of the attiéké consumed in the town of Daloa comes from local producers. They sold $87 \%$ of their production inside the city and $13 \%$ is conveyed outside (Figure $2 \mathrm{~b}$ ). 


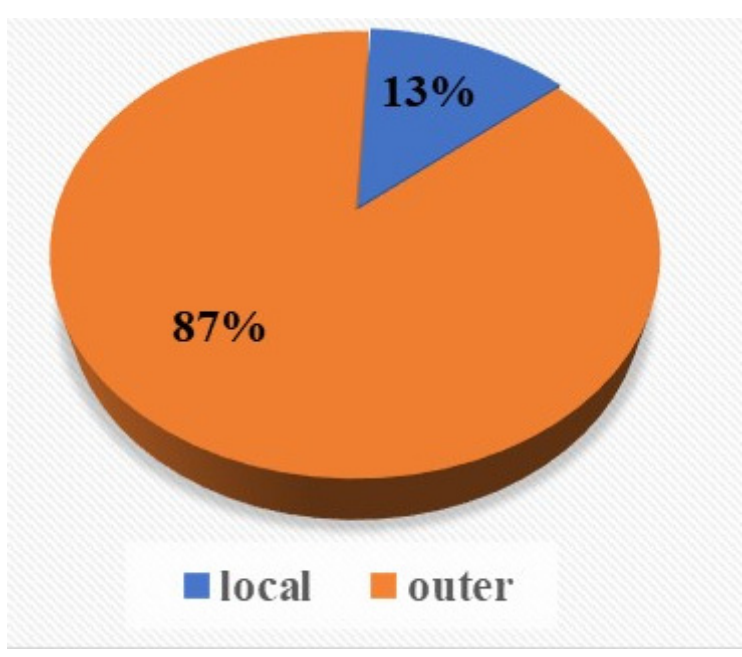

a

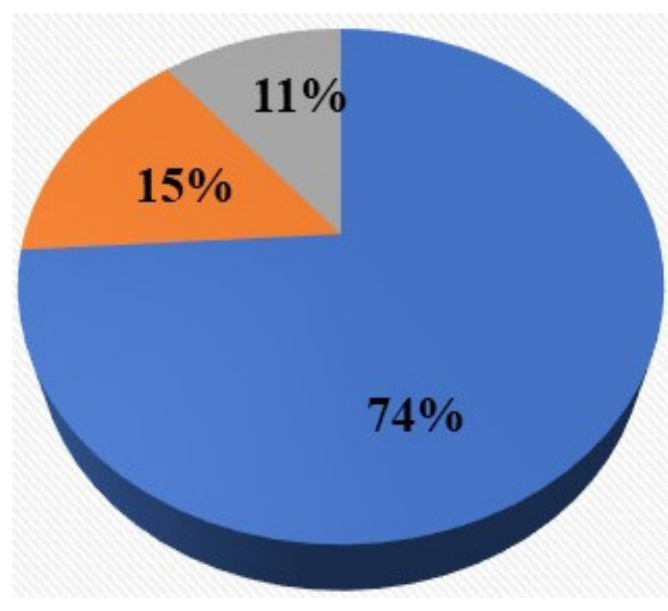

- $[200 \mathrm{Kg}-300 \mathrm{Kg}]$

[ $[300 \mathrm{Kg}-450 \mathrm{Kg}]$

[ [450 Kg and more]

Figure 2. Production of attiéké. a/ Distribution rate of attiéké produced in Daloa; b/ Weekly production of attiéké

\subsubsection{Shelf-life of Attiéké}

Figure 3 a showed that $17 \%$ and $49 \%$ of female producers keep attiéké for 1 and 2 days respectively after manufacture.

The production of $31 \%$ of them were entirely sold after 3 days maximum and $3 \%$ needed more than 4 days from the day of manufacture to sell their attiéké.

Saleswomen revealed that $35 \%$ of traders sell their entire delivery in 2 days and $20 \%$ in 1 day. On the other hand, 37\% estimate that they sell out in 3 days and $8 \%$ after more than 4 days. (Figure 3b). 


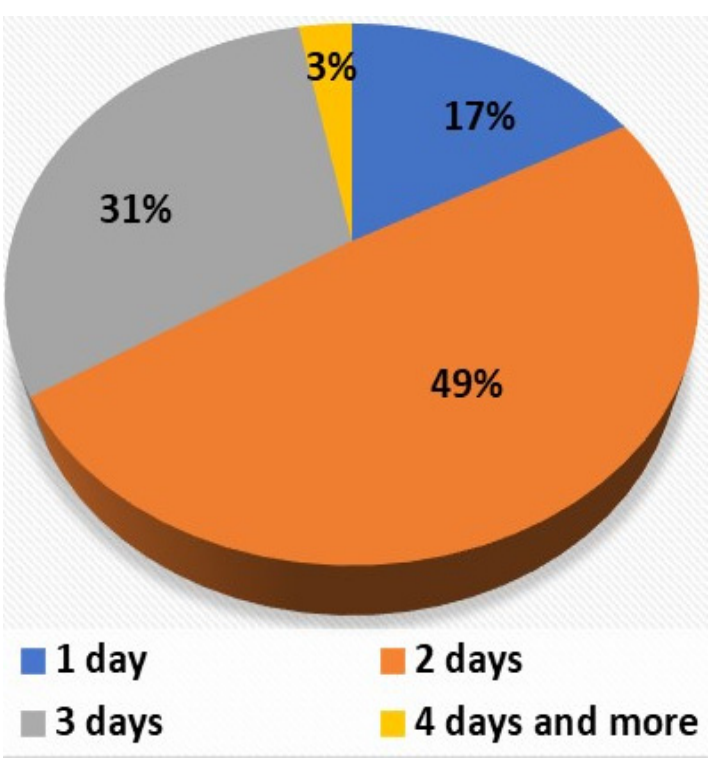

a

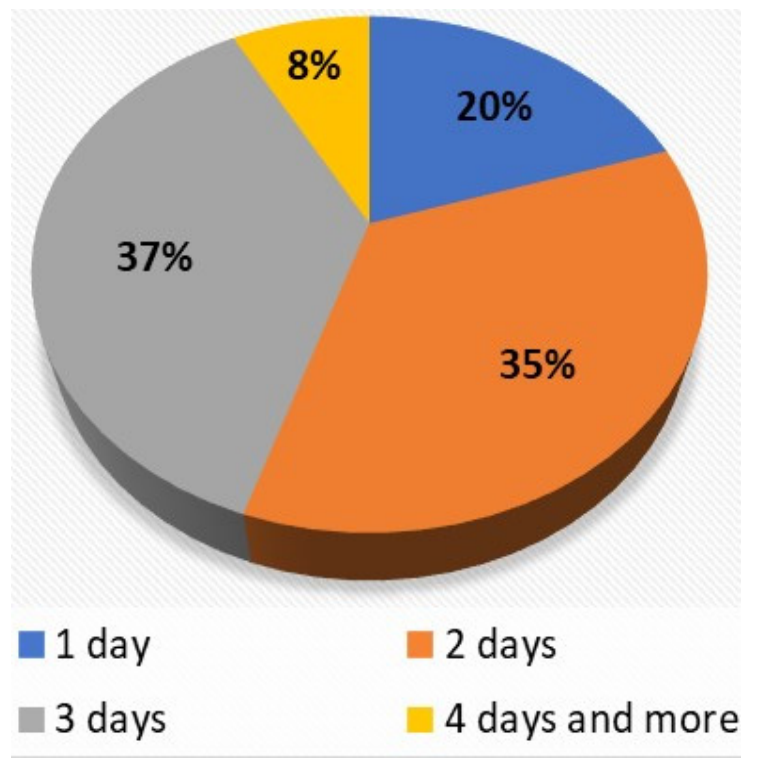

b

Figure 3. Conservation time of attiéké: a) Conservation time (maker); b) conservation time (sales clerk)

\subsubsection{Microbiological Characteristics of Attiéké-women}

Microbiological analysis of attiéké samples showed the presence of high concentration of mesophilic aerobic germs. The values found were $9.10^{7} \mathrm{cfu} / \mathrm{g}, 1.10^{8} \mathrm{cfu} / \mathrm{g}, 1.28 .10^{7} \mathrm{cfu} / \mathrm{g}$, $1.36 .10^{7} \mathrm{cfu} / \mathrm{g}, 2.6 .10^{7} \mathrm{cfu} / \mathrm{g}$ for the Evéché (EVE), Huberson (HUB), Labia (LAB), Orly (ORL) and Gbokora (GBO) districts respectively. As for the Commerce (COM), Tazibouo(TAZ), Kennedy (KEN), Lobia (LOB) and Gbéville (GBE) neighbourhoods, the charges obtained were respectively $1.26 .10^{7} \mathrm{cfu} / \mathrm{g}, 2.28 .10^{7} \mathrm{cfu} / \mathrm{g}, 1.25 .10^{7} \mathrm{cfu} / \mathrm{g}, 2.28 .10^{7}$ $\mathrm{cfu} / \mathrm{g}$ and $1.37 .10^{7} \mathrm{cfu} / \mathrm{g}$. The highest mesophilic aerobic load was observed in the Huberson area at $1.10^{8} \mathrm{cfu} / \mathrm{g}$.

Concerning the yeast and mould contents, the rates were $2.10^{7} \mathrm{cfu} / \mathrm{g}, 1.89 .10^{7} \mathrm{cfu} / \mathrm{g}, 2.10^{7}$ $\mathrm{cfu} / \mathrm{g}, 1.4 .10^{7} \mathrm{cfu} / \mathrm{g}, 2.1 .10^{6} \mathrm{cfu} / \mathrm{g}$ respectively for the Evéché, Huberson, Labia, Orly and Gbokora districts. The Commerce, Tazibouo, Kennedy, Lobia and Gbéville neighbourhoods had respective contents of $3.10^{7} \mathrm{cfu} / \mathrm{g}, 2.71 .10^{6} \mathrm{cfu} / \mathrm{g}, 2.7 .10^{7} \mathrm{cfu} / \mathrm{g}, 3.10^{7} \mathrm{cfu} / \mathrm{g}$, and $3.10^{7}$ $\mathrm{cfu} / \mathrm{g}$. The Commerce, Gbéville and Orly districts recorded the highest loads $\left(3.10^{7} \mathrm{cfu} / \mathrm{g}\right)$ of yeasts and moulds.

All samples analysed were free of total coliforms, except for three samples to district Commerce $\left(1.5 \cdot 10^{7} \mathrm{cfu} / \mathrm{g}\right)$, Lobia $\left(8.6 .10^{7} \mathrm{cfu} / \mathrm{g}\right)$, Gbéville $\left(2.1 .10^{7} \mathrm{cfu} / \mathrm{g}\right)$.

With regard to fecal coliforms, only the Commerce and Gbéville districts showed contamination. A load of $1.4 .10^{4} \mathrm{cfu} / \mathrm{g}$ for the Commerce district and 2.2.10 $\mathrm{cfu} / \mathrm{g}$ for the Gbéville district.

The presence of Salmonella was not detected in any of the samples analysed (Figure 4). 


\section{I Macrothink}

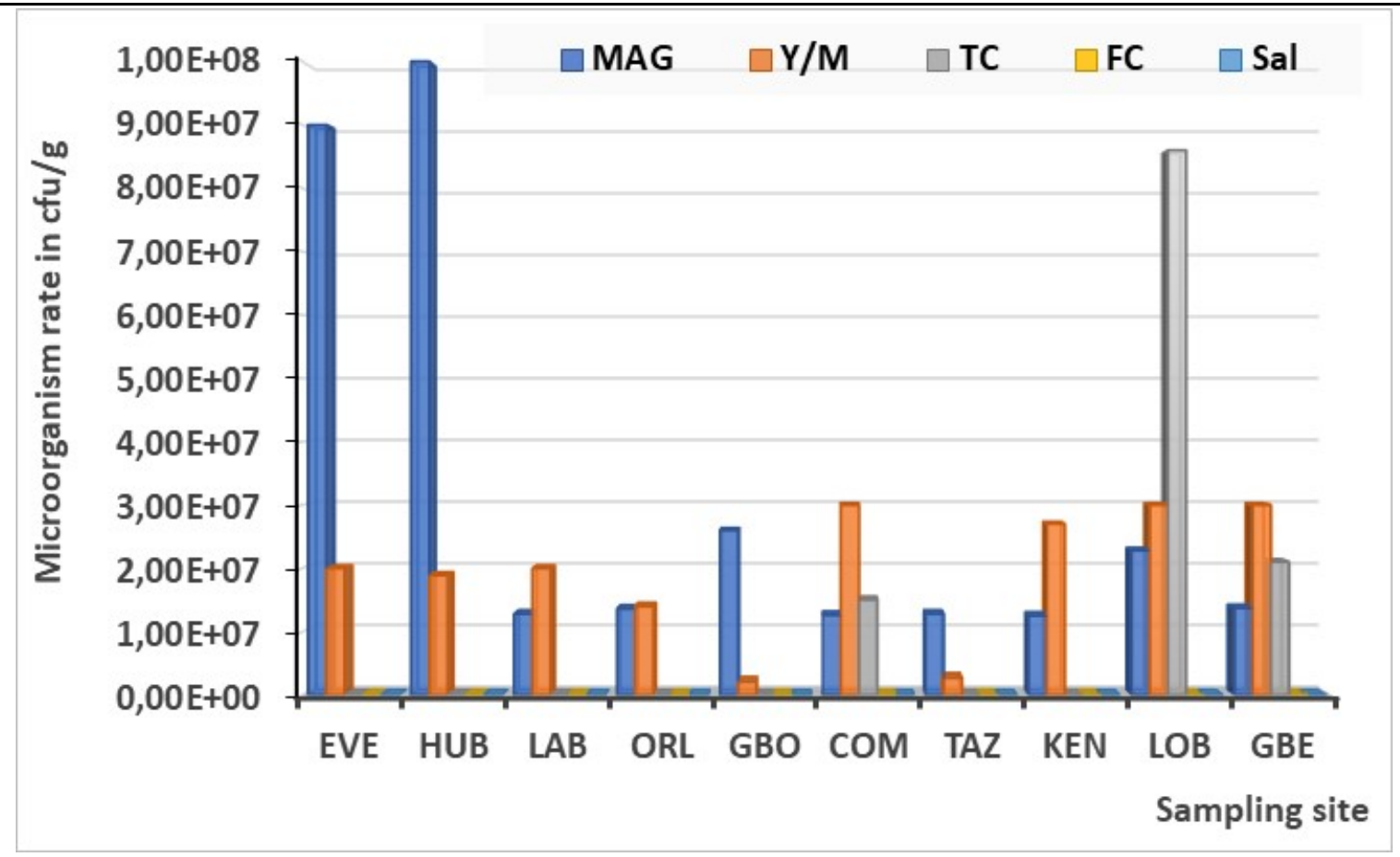

Figure 4. Microorganism content of attiéké-women. Y/M: Yeasts and molds; TC: Total coliforms; FC: Fecal Coliforms, MAG: mesophilic aerobic Germs; SAL: Salmonella

\subsubsection{Microbiological Characteristics of Attiéké-garba}

Microbiological studies carried out on the different samples have allowed the enumeration of microorganisms such as mesophilic aerobic germs, yeasts and moulds. The contents of mesophilic aerobic germs gave $1.95 .10^{7} \mathrm{cfu} / \mathrm{g}$ for Tazibouo, $5.7 .10^{6} \mathrm{cfu} / \mathrm{g}$ for Lobia, 5.7.10 $\mathrm{cfu} / \mathrm{g}$ for Commerce, $6.10^{6} \mathrm{cfu} / \mathrm{g}$ for Gbokora and with Gbéville a load of $2.68 .107 \mathrm{cfu} / \mathrm{g}$. Moreover, the analysis of the samples in the Orly, Labia, Kennedy, Huberson and Evéché districts revealed respectively values such as $7.10^{4} \mathrm{cfu} / \mathrm{g}, 2.34 .10^{6} \mathrm{cfu} / \mathrm{g}, 1.91 .10^{7} \mathrm{cfu} / \mathrm{g}$, $1.89 .10^{8} \mathrm{cfu} / \mathrm{g}$ and $8.2 .10^{5} \mathrm{cfu} / \mathrm{g}$. The high mesophilic aerobic germ load at Huberson was $1.8910^{8} \mathrm{cfu} / \mathrm{g}$.

For yeasts and moulds, the rates revealed are $2.10^{7} \mathrm{cfu} / \mathrm{g}$ for Tazibouo, $1.89 .10^{7} \mathrm{cfu} / \mathrm{g}$ for Lobia, $2.10^{7} \mathrm{cfu} / \mathrm{g}$ for trade, $1.4 .10^{7} \mathrm{cfu} / \mathrm{g}$ for gbokora, and $2.1 .10^{6} \mathrm{cfu} / \mathrm{g}$ for gbéville. The Orly, Labia, Kennedy Huberson, and Evéché districts showed contents of $3.10^{7} \mathrm{cfu} / \mathrm{g}$, $2.71 .10^{6} \mathrm{cfu} / \mathrm{g}, 2.7 .10^{7} \mathrm{cfu} / \mathrm{g}, 1.89 .10^{8}$ and $3.10^{7} \mathrm{cfu} / \mathrm{g}$ respectively. The Huberson area had a high level of $1.89 .10^{8} \mathrm{cfu} / \mathrm{g}$ of yeasts and moulds.

As for total and fecal coliforms, an absence is marked in all samples of attiéké-garba. The presence of Salmonella was also not detected in any of the samples analyzed (Figure 5). 


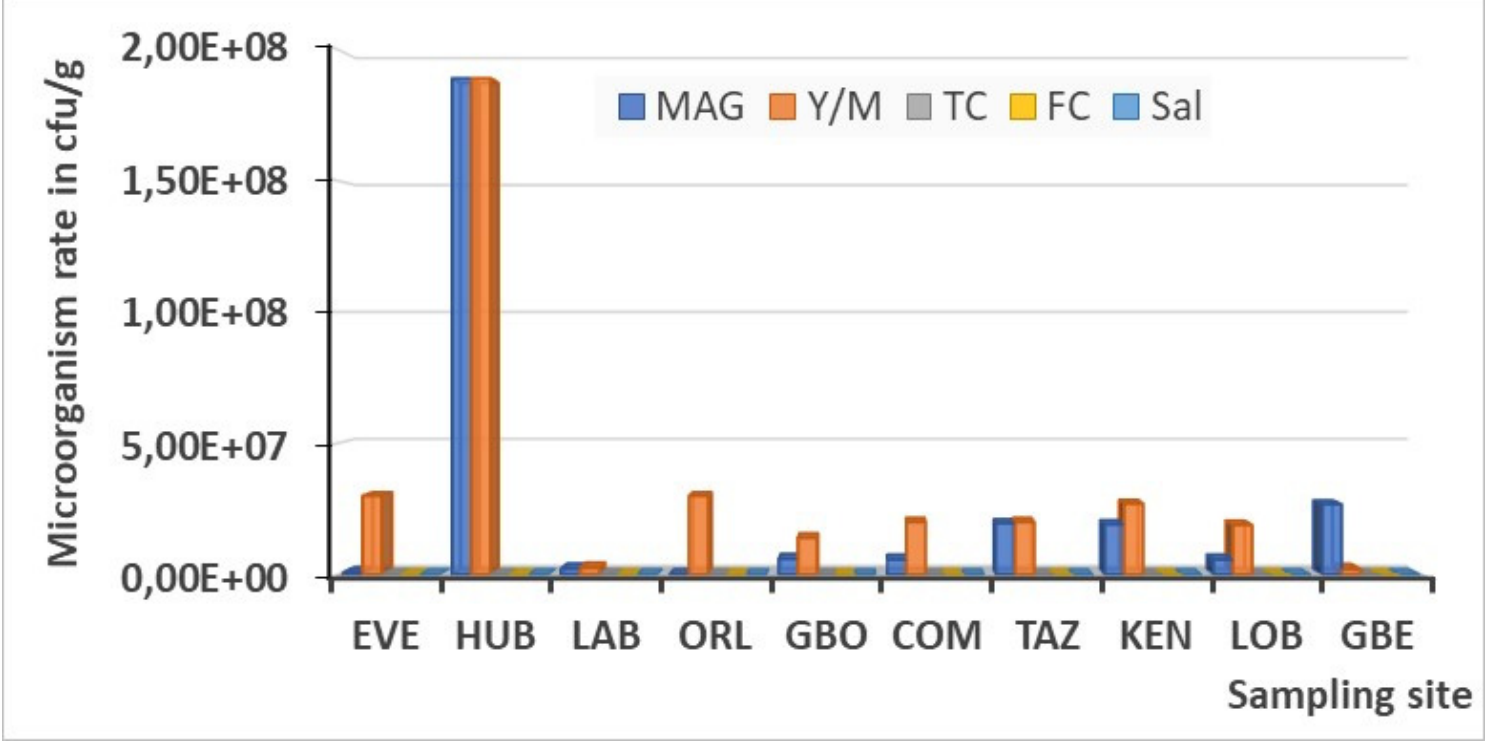

Figure 5. Microorganism content of attiéké-Garba. Y/M: Yeasts and molds; TC: Total coliforms; FC: Fecal Coliforms, MAG: mesophilic aerobic Germs, SAL: Salmonella

\subsubsection{Microbiological Comparison of the Two Types of Attiéké}

This comparison highlights the average loadings of these microorganisms obtained in the samples taken (Figure 6). The average content of aerobic germs in attiéké-femme is $6.10^{6}$ $\mathrm{cfu} / \mathrm{g}$ as opposed to $2.10^{6} \mathrm{cfu} / \mathrm{g}$ obtained in attiéké-garba. Yeasts and moulds yielded 2.7.10 $\mathrm{cfu} / \mathrm{g}$ in the samples of attiéké-femme and $3.1 .10^{6} \mathrm{cfu} / \mathrm{g}$ in attiéké-garba. In addition, the mean loads of total coliforms and relatively low faecal coliforms obtained only in attiéké-female were $1.4 .10^{3} \mathrm{cfu} / \mathrm{g}$ and $1.6 .10^{3} \mathrm{cfu} / \mathrm{g}$ respectively.

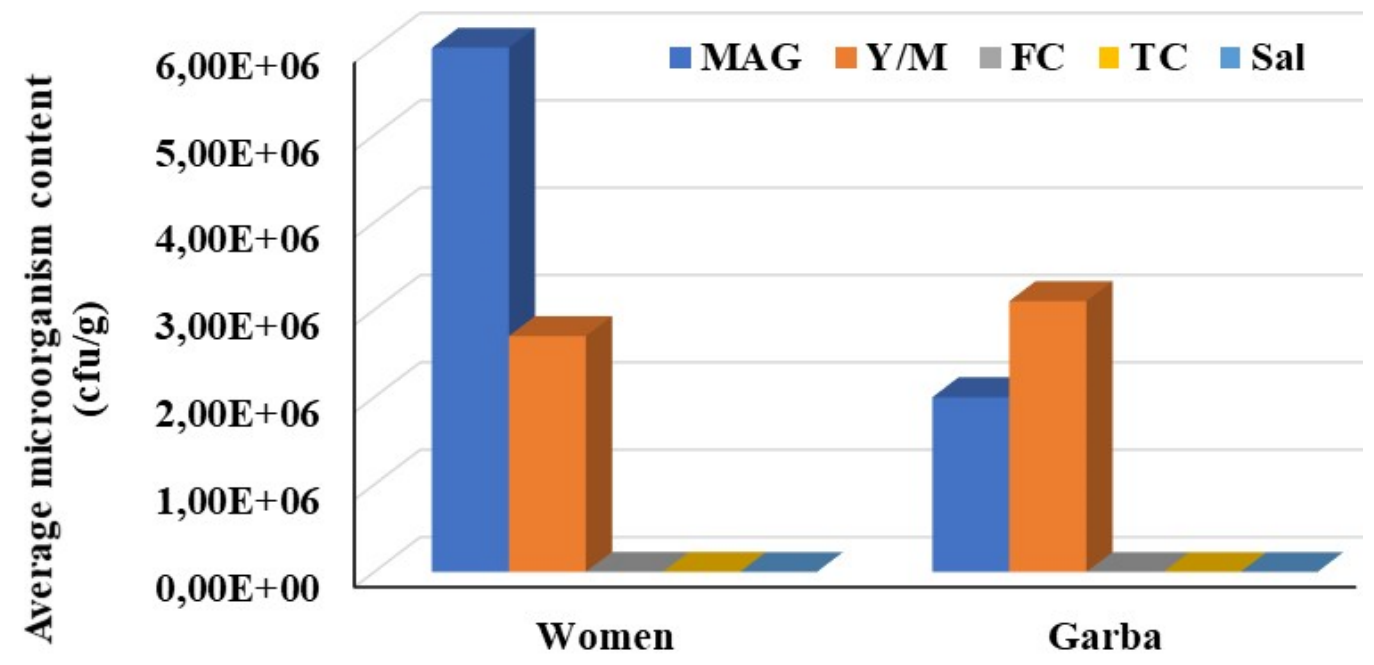

Figure 6. Comparison of the microbiological quality of attiéké-garba and attiéké-women 


\subsection{Discussion}

The results of the survey of this study showed that the weekly production of attiéké is $74 \%$ for an average of $250 \mathrm{~kg}$, which specifies the general activity of attiéké manufacture also described by Krabi et al. (2015). Also, 87\% of attiéké production is served in Daloa and 13\% is conveyed to the outside. This difference would be explained by the high consumption of attiéké by the population of Daloa. In addition, the producers keep attiéké for 2 days and the sellers keep it for more than 2 days before all their goods are sold. This could alter the quality of attiéké, because according to Sahore \& Nemlin (2010), attiéké has a short conservation period.

Concerning the microbiological aspect, the analyses made it possible to evaluate the level of contamination of attiéké sold directly for consumption in the town of Daloa. The examination identified the flora of alteration, yeasts, molds, total coliforms and salmonella. This spoilage flora, consisting of the total mesophilic aerobic flora with the highest content $\left(1.10^{8} \mathrm{cfu} / \mathrm{g}\right)$ is obtained in the Huberson district for attiéké-woman and a high content of $\left(1.98 .10^{8} \mathrm{cfu} / \mathrm{g}\right)$ in the Huberson district for attiéké-garba. These results are in agreement with those of Dedjedji et al. (2008) on attiéké sold on the market in certain districts of Abidjan. According to Kasse et al. (2014), the high load of mesophilic aerobic germs would favour a strong spoilage and constitute a risk for consumption. It would also be linked to the shelf life of attiéké and the hygiene of each seller.

In addition, the analysis of yeast and moulds revealed the highest loads in this study after the GAM study. The high load obtained in the Commerce, Gbéville, Orly neighbourhoods is $\left(3.10^{7} \mathrm{cfu} / \mathrm{g}\right)$ for attiéké-femme and for attiéké-garba the highest content $\left(1.89 .10^{8}\right)$ was in the Huberson neighbourhood. These high loads would be due to the temperature and humidity of the plastics in which the attiéké is packed after manufacture. According to Dragacci et al. (2011), these parameters are growth factors due to their rapid development generally after 2 to 3 days. Nguyen (2007) in his study identified molds that once ingested in large numbers produce diseases in humans called mycoses, some toxin producers give diseases called mycotoxicoses. Several molds including the genera Aspergillus, Penicillium and Fusarium are known to be contaminants of agricultural products and/or for their ability to produce toxic secondary metabolites (Meyer et al., 2004).

As for total coliforms, also called coliforms at $37^{\circ} \mathrm{C}$, their presence was noticed in only three samples. The highest value $\left(8.6 .10^{7}\right)$ was obtained in the Lobia district. Their presence in a food does not necessarily imply fecal contamination, but certainly an unhygienic product. Furthermore, according to Bourgeois et al. (1988), the absence of total coliforms does not necessarily mean that the food is safe to eat.

In terms of fecal coliforms, two neighbourhoods showed results, with a high value recorded in the Commerce district $\left(1.4 .10^{4} \mathrm{cfu} / \mathrm{g}\right)$. The absence of fecal coliforms in attiéké samples indicates that they can be consumed without major risk of intoxication. Their presence in a food would be related to the handling of water washing fish.

An additional precaution led to the search for salmonella in the samples analysed. The total 
absence of pathogen (Salmonella) has allowed us to affirm that the pathogenicity aspect of the samples is preserved despite the microbial load in the samples. These results are in agreement with those of Kouassi et al. (2008) which confirms that attiéké can be easily consumed without any particular risk of contamination. For the comparison of attiéké-women and attiéké-garba, greater contamination was observed in attiéké-women. This contamination would be due to the neighbourhood, the storage time, or the storage locations. Indeed, the attiéké-garba is sold more in the high standing neighbourhoods whereas the attiéké-women is sold more in the precarious neighbourhoods of the city of Daloa.

\section{Conclusion:}

This study shows that despite the growth of attiéké, its production remains informal and tranditional. The results of the study show that the storage time of attiéké exposes fresh attiéké more to possible contamination by environmental microorganisms and air.

Thus, attiéké can represent a risk of toxi-infection for the consumer during storage. Contamination by microorganisms is observed according to the standing of the districts. Thus, it is recommended

Training of women producers in food safety (food hygiene),

The establishment of a policy for the management of waste from this activity, particularly at the level of the working environment in order to avoid cross-contamination of the finished product.

\section{References}

Assanvo, J. B., Agbo, G. N., Behi, Y. E. N., Coulin, P., \& Farah Z. (2006). Microflora of traditional starter made from cassava for attiéké production in Dabou (Côte d'Ivoire). Food Control, 17, 37-41. https://doi.org/10.1016/j.foodcont.2004.08.006

Assanvo, J. B., Agbo, G. N., Behi, Y. E. N., Coulin, P., \& Farah Z. (2002). La microflore du ferment du manioc pour la production de l'attiéké adioukrou de Dabou (Côte d'Ivoire); BIOTERRE, Revue Internationale des Sciences de la Vie et de la Terre, $\mathrm{N}^{\circ}$ spécial, Acte du Colloque International (pp. 286-299). Centre Suisse de Recherche Scientifique.

Bourgeois, C. M., \& Leveau, J. Y. (1988). La microflore aérobie mésophile. Techniques d'analyse et de contrôle dans les industries agro-alimentaires (3rd 3ed). Paris: Lavoisier. pp. 139-140.

Coulin P., Farah Z., Assanvo J. B., Spillmann J., \& Puhan Z. (2006). Characterisation of the microflora of the fermented cassava product attiéké during traditional small-scale preparation. International Journal of Food Microbiology, 106, 131-136. https://doi.org/10.1016/j. ijfoodmicro.2005.06.012

Dédédji, M. M., Ahouansou, R., \& Hounhouigan, D. J. (2008). Evaluation des performances techniques d'un granuleur mécanique pour la production d'attiéké (couscous de manioc) au Benin. Bulletin de la Recherche Agronomique du Benin, 61, 7-16. 
Djè, K. M., Djéni, N. T., Toka M. D., \& Aka S. (2008). Biochemical and microbiological changes of cassava dough fermenting under different temperature conditions. Journal of Food Technology, 6(3), 114-119.

Djéni, N. T., N'Guessan, K. F., Toka D. M., Kouamé, K. A., \& Dje, K.M. (2011). Quality of attiéké (a fermented cassava product) from the three main processing zones in Côte d'Ivoire. Food Research International, 44, 410-416. https://doi.org/10.1016/j.foodres.2010.09.032

Dragacci, S., Zakhia-Rosis N., \& Galtier P. (2011). Dangers dans l'assiette, collection Carnets de science, Editions Quae.

Kacou, A. C. (2000). Optimisation des conditions d'application d'une méthode de conservation longue durée de la pâte de manioc (Manihot esculenta Crantz) en vue d'améliorer la qualité alimentaire de l'attiéké et du placali. Thèse de Doctorat, Université de Cocody (Abidjan-Côte d'Ivoire).

Kasse, M., Cissé, M., Touré, A., Ducamp-Collin, M. N., Guisse, A. (2014). Qualité microbiologique des tranches de mangues (Mangifera indica L.) vendues à Dakar (Sénégal) International. Journal of Biological and Chemical Sciences, 8(4), 1611-1619. https://doi.org/10.4314/ijbcs.v8i4.23

Kouassi, B. Y., Traoré A., \& Sirpé, G. (2008). Transformation et consommation des denrées alimentaires en Afrique de l'ouest centrale. Editions.

Krabi, E. R., Assamoi, A. A., Ehon, A. F., Bréhima D., Niamké, L. S., \& Thonart, P. (2015). Production d'attieke (couscous à base de manioc fermente) dans la ville d'Abidjan. European Scientific Journal, 11(15), 277-292.

Kouadio, J. H. (2012). Ochratoxinea en Côte d'Ivoire: moisissures ochratoxinogènes exposition humaine et détoxification des aliments. Revue Ivoirienne des Sciences et Technologie, 20, 87-103.

Meyer, A., Deiana, J., Bernard, A. (2004). Cours de microbiologie générale avec problèmes et exercices. (2nd ed.) DOIN. Biosciences et Techniques. p. 437.

Nguyen, M. T. (2007). Identification des espèces de moisissures, potentiellement productrices de mycotoxines dans le riz commercialisé dans cinq provinces de la région centrale du Vietnam - étude des conditions pouvant réduire la production des mycotoxines. Thèse de docteur de l'Institut National Polytechnique de Toulouse-France. p. 147

Sahoré, D. A., \& Nemlin, G. J. (2010). Effect of technological treatments on cassava (Manihot esculenta Crantz). Food and Nutrition Sciences, 1, 19-23. https://doi.org/10.4236/fns.2010. 11004

Yao, K. J., Koffi, R. A. \& Aboua, F. (2006). Composition of dehydrated attiéké powder. Tropical Science, 46(4), 224-226. https://doi.org/10.1002/ts. 182

Yéboué, K. H., Amoikon, K. E., Kouamé, K. G., \& Kati-Coulibaly S. (2017). Valeur nutritive et propriétés organoleptiques de l'attiéké, de l'attoukpou et du placali, trois mets à base de 
manioc, couramment consommés en Côte d'Ivoire. Journal of Applied Biosciences, 113, 11184-11191. https://doi.org/10.4314/jab.v113i1.7

\section{Copyright Disclaimer}

Copyright reserved by the author(s).

This article is an open-access article distributed under the terms and conditions of the Creative Commons Attribution license (http://creativecommons.org/licenses/by/4.0/). 